\title{
Sperm ultrastructure of shrimps from the family Penaeidae (Crustacea: Dendrobranchiata) in a phylogenetic context
}

\author{
Tavani Rocha Camargo a, *, Natalia Rossi ${ }^{\text {b, e }}$, Antonio L. Castilho ${ }^{c}$, Rogério C. Costa ${ }^{\mathrm{d}}$, \\ Fernando L. Mantelatto ${ }^{b}$, Fernando José Zara ${ }^{a}$ \\ a Laboratório de Morfologia de Invertebrados (IML), Departamento de Biologia Aplicada, CAUNESP and IEAMar, Universidade Estadual Paulista (UNESP), \\ FCAV, Jaboticabal, SP, Brazil \\ ${ }^{\mathrm{b}}$ Laboratório de Bioecologia e Sistemática de Crustáceos (LBSC), Departamento de Biologia, Faculdade de Filosofia, Ciências e Letras de Ribeirão Preto \\ (FFCLRP), Universidade de São Paulo (USP), Av. Bandeirantes, 3900, 14040-901, Ribeirão Preto, SP, Brazil \\ ${ }^{\mathrm{C}}$ Laboratório de Carcinologia, Departamento de Zoologia, Instituto de Biociências, Universidade Estadual Paulista (UNESP), Distrito de Rubião Júnior, S/N, \\ 18618-970, Botucatu, SP, Brazil \\ d Laboratório de Biologia de Camarões Marinhos e de Água Doce (LABCAM), Departamento de Ciências Biológicas, Faculdade de Ciências, Universidade \\ Estadual Paulista (UNESP), Av. Luiz Edmundo Carrijo Coube n 14-01, Bairro Vargem Limpa, 17033-360, Bauru, SP, Brazil \\ ${ }^{\mathrm{e}}$ Instituto de Ciências Biológicas (ICB), Universidade Federal de Goiás, Av. Esperança, s/n, Campus Samambaia (Campus II) ICB 01: sala -18, 74690-900, \\ Goiânia, GO, Brazil
}

\section{A R T I C L E I N F O}

\section{Article history:}

Received 25 April 2016

Received in revised form

4 September 2016

Accepted 30 January 2017

Available online 27 March 2017

\section{Keywords:}

Sperm ultrastructure

Molecular phylogeny

Transmission electron microscopy

Bayesian inference

Decapoda

\begin{abstract}
A B S T R A C T
We describe the sperm ultrastructure of six penaeid species, including at least one member of each tribe (Penaeini, Parapenaeini and Trachypenaeini). Fragments of the vas deferens of the Penaeidae Farfantepenaeus brasiliensis, Farfantepenaeus paulensis, Litopenaeus schmitti, Parapenaeus americanus, Rimapenaeus constrictus and Xiphopenaeus kroyeri were fixed and processed according to the routine for transmission electron microscopy. The morphological results were contextualized in an evolutionary perspective using molecular markers for the phylogenetic reconstruction of this group. A phylogram was proposed by Bayesian inference based on $1007 \mathrm{bp}$ of 33 sequences of the combined genes (16S rDNA and COI mtDNA) from 27 dendrobranchiate specimens. Our findings show that morphological differences in the sperm ultrastructures of members among the tribes of Penaeidae can be used as a baseline to understand their evolutionary relationships. Individuals from the Penaeini tribe show plesiomorphic characteristics in the sperm ultrastructure compared to the Trachypenaeini tribe from which they were derived, such as shrimp from family Sicyoniidae. The morphological complexity of the sperm of the different penaeid members corroborated with the genetic phylogeny, which showed different clades for each tribe and the close relationship with Sicyoniidae. The sperm features of the selected species studied here reflected their evolutionary history. These features confirm the previous phylogenetic hypothesis and question the monophyly of Penaeidae, which should be verified in the future with a more complete set of representative members of each tribe.
\end{abstract}

() 2017 Elsevier Ltd. All rights reserved.

\section{Introduction}

The family Penaeidae Rafinesque, 1815 is comprised of 215 shrimp species classified into 33 genera (Pérez-Farfante and Kensley, 1997; De Grave and Fransen, 2011), which can be split into three tribes: Penaeini, Parapenaeini and Trachypenaeini (Burkenroad, 1983). These shrimp play an important role in the

\footnotetext{
* Corresponding author

E-mail address: rochatavani@gmail.com (T.R. Camargo).
}

marine ecosystem and some of them are commercially important (Pérez-Farfante, 1988). On the Brazilian coast, there are 61 species of the suborder Dendrobranchiata. Four of these species are the most common and are very important economically: Farfantepenaeus brasiliensis (Latreille, 1817), Farfantepenaeus paulensis (Pérez Farfante, 1967), Litopenaeus schmitti (Burkenroad, 1936) and Xiphopenaeus kroyeri (Heller, 1862) (Costa et al., 2003).

The number of studies on reproductive aspects in penaeid available in the literature is relatively high. To summarize, there are studies concerning sperm transference, activation, capacitation (Bauer, 1991; Alfaro et al., 2003, 2007), reproductive condition, 
male reproductive system morphology, spermatophore formation (Malek and Bawab, 1974; Chow et al., 1991; Bauer and Min, 1993; Alfaro-Montoya, 2010) and the sperm ultrastructure of other members of the Superfamily Penaeoidea (Clark et al., 1973; Kleve et al., 1980; Medina et al., 1994a, b; Alfaro et al., 2003; Scelzo and Medina, 2003; Braga et al., 2013a, b; Camargo et al., 2016). However, the approach regarding the sperm ultrastructure is still incipient considering the great diversity of this family. Despite a promising perspective, there are not enough descriptions of the sperm ultrastructure for species that occur along the Brazilian coast.

Studies on sperm ultrastructure confirmed that these characteristics showed good phylogenetic signals and were very efficient tools to support taxonomic issues involving phylogenetic relationships among decapod crustaceans (Jamieson, 1991; Medina et al., 1994a, b; Medina, 1995; Jamieson and Tudge, 2000; Tudge, 2009). However, there is a gap in the knowledge on the sperm ultrastructure of the diverse shrimps of the suborder Dendrobranchiata (Table 1 ), and only $4.6 \%$ of the 533 recognized species of this group show the described sperm morphology (Jamieson and Tudge, 2000; Tudge, 2009). Additionally, only $5.5 \%$ of the penaeid species have undergone spermiotaxonomic evaluation.

According to Medina et al. (2006a), the members of the Aristeidae Wood-Mason and Alcock, 1891 show primitive sperm morphology and consequently are considered to be the basal branch in the phylogenetic hypothesis of the group. The members do not have an extension of the acrosome that forms the spike, which is considered the exception to the typical morphology of Penaeoidea and for some species of Sergestoidea Dana, 1852 (Medina et al., 2006a). Conversely, the members of Sicyoniidae Ortmann, 1898 exhibit a complex subacrosomal region, which is considered an intermediary ultrastructural trait between Aristeidae and Penaeidae (Kleve et al., 1980; Medina et al., 1994a, b; Scelzo and Medina, 2003; Braga et al., 2013a). The latter includes individuals with simpler elements of the subacrosomal region, similar to the species of Solenoceridae Wood-Mason and Alcock, 1891, which is the most derivative group (Scelzo and Medina, 2003; Braga et al., 2013a).

In contrast, Ma et al. (2009) proposed a phylogeny based on nuclear genes, with two evolutionary lineages for the members of the superfamily Penaeoidea. In this study, the Trachypenaeini tribe of the Penaeidae family and the Sicyoniidae family were positioned in the same clade, while Aristeidae, Benthesicymidae Wood-Mason and Alcock, 1891 and Solenoceridae were located together in a separate clade. However, the sperm ultrastructure of the species of Trachypenaeini was only described under the scanning electron microscopy (Bauer and Min, 1993; Alfaro et al., 2003) and, no information is available concerning how complex the sperm is under the transmission electron microscope. Therefore, there is no consensus between the phylogenetic hypotheses based on morphological or molecular data. One of the reasons for the incongruence among the relationships between members of the superfamily Penaeoidea is the lack of correlation between the morphological descriptions and molecular information.

Thus, the sperm ultrastructure of six species of Penaeidae from the Brazilian coast, including at least one member each of the Parapenaeini, Penaeini and Trachypenaeini tribes, were described and compared with the literature. Furthermore, the results were correlated with the phylogenetic hypothesis proposed by the mitochondrial genes (16S rDNA and COI mtDNA) from some species of the superfamily Penaeoidea to explore the biological diversity in an evolutionary context.

\section{Materials and methodology}

\subsection{Biological samples}

The mature males of the Penaeini (F. brasiliensis, F. paulensis and L. schmitti) and Trachypenaeini [Rimapenaeus constrictus (Stimpson, 1871 ) and $X$. kroyeri] used in the morphological analysis were

Table 1

Species of Dendrobranchiata shrimp with described sperm ultrastructure.

\begin{tabular}{|c|c|c|}
\hline Family & Species & Source \\
\hline \multicolumn{3}{|l|}{ Penaeidae } \\
\hline \multirow[t]{10}{*}{ Penaeini } & Farfantepenaeus brasiliensis (Latreille, 1817) & Present study \\
\hline & Farfantepenaeus paulensis (Pérez-Farfante, 1967) & Braga et al. (2013b), present study \\
\hline & Farfantepenaeus aztecus (Ives, 1891) & Clark et al. (1973) \\
\hline & Litopenaeus occidentalis (Streets, 1871) & Alfaro et al. (2007) \\
\hline & Litopenaeus schmitti (Burkenroad, 1936) & Fransozo et al. (2016), present study \\
\hline & Litopenaeus stylirostris (Stimpson, 1871) & Alfaro et al. (2007) \\
\hline & Litopenaeus vannamei (Boone, 1931) & Alfaro et al. (2007) \\
\hline & Litopenaeus setiferus (Linnaeus, 1767) & Krol et al. (1992) \\
\hline & Marsupenaeus japonicus (Spence Bate, 1888) & Medina et al. (1994a) \\
\hline & Penaeus kerathurus Forskal, 1175 & Medina et al. (1994a) \\
\hline \multirow[t]{4}{*}{ Parapenaeini } & Artemesia longinaris Spence Bate, 1888 & Scelzo and Medina (2003) \\
\hline & Parapenaeus americanus Rathbun, 1901 & Present study \\
\hline & Parapenaeus longirostris (Lucas, 1846) & Medina (1994) \\
\hline & Penaeopis serrata Spence Bate, 1881 & Medina et al. (1994b) \\
\hline \multirow[t]{2}{*}{ Trachypenaeini } & Rimapenaeus constrictus (Stimpson, 1871) & Present study \\
\hline & Xiphopenaeus kroyeri (Heller, 1862) & Present study \\
\hline \multirow[t]{4}{*}{ Aristeidae } & Aristaeomorpha foliacea (Risso, 1827) & Medina (1995) \\
\hline & Aristeopsis edwardsiana (Johnson, 1867) & Medina et al. (2006a) \\
\hline & Aristeus antennatus Risso, 1816 & Demestre and Fortuñu (1992) \\
\hline & Aristeus varidens Holthuis, 1952 & Medina et al. (2006a) \\
\hline \multirow[t]{3}{*}{ Solenoceridae } & Pleoticus muelleri (Spence Bate, 1816) & Medina et al. (2006b) \\
\hline & Solenocera africana Stebbing, 1917 & Medina et al. (2006b) \\
\hline & Solenocera membranacea (Risso, 1816) & Medina et al. (2006b) \\
\hline \multirow[t]{4}{*}{ Sicyoniidae } & Sicyonia carinata (Brünnich, 1768) & Medina et al. (1994b) \\
\hline & Sicyonia dorsalis Kingsley, 1878 & Camargo et al. (2016) \\
\hline & Sicyonia ingentis (Burkenroad, 1938) & Kleve et al. (1980) \\
\hline & Sicyonia typica (Boeck, 1864) & Camargo et al. (2016) \\
\hline \multirow[t]{2}{*}{ Sergestidae } & Sergestes arcticus (Krøyer, 1855) & Medina (1995) \\
\hline & Peisos petrunkevitchi Burkenroad, 1945 & Scelzo and Medina (2004) \\
\hline
\end{tabular}


collected from July, 2011 to August 2015 in the Cananéia and Ubatuba regions, São Paulo, Brazil $\left(23^{\circ} 27^{\prime} 24^{\prime \prime} \mathrm{S} / 45^{\circ} 01^{\prime} 20^{\prime \prime} \mathrm{W}\right.$ and $25^{\circ} 07^{\prime} 385^{\prime \prime} \mathrm{S} / 47^{\circ} 52^{\prime} 508^{\prime \prime} \mathrm{W}$, respectively) by double-rig shrimp trawling. All individuals were identified according to Costa et al. (2003) and transported alive to the Invertebrates Morphology Laboratory (IML) at the Department of Biology of the Faculty of Agricultural and Veterinary Sciences at the Jaboticabal Campus (FCAV) at the University of São Paulo State (UNESP). The species of the tribe Parapenaeini (Parapenaeus americanus Rathbun, 1901) was collected in São Sebastião, São Paulo Brazil (24 $08^{\prime} 76^{\prime \prime}$ S/ $45^{\circ} 02^{\prime} 16^{\prime \prime} \mathrm{W}$ ), also by trawling using the research vessel "Soloncy Moura" at a $78 \mathrm{~m}$ depth and submitted to a transmission electron microscopic procedure on board. All animals $(n=64)$ were coldanesthetized and dissected to remove the male reproductive system.

\subsection{Sperm ultrastructure}

The distal vas deferens fragments $\left(1 \mathrm{~mm}^{3}\right)$ were fixed for $3-4 \mathrm{~h}$ in Karnovsky fixative solution for marine shrimp (2.5\% glutaraldehyde and $2 \%$ paraformaldehyde) in a $0.1 \mathrm{M}$ sodium cacodylate buffer (pH 7.6) containing 5\% sucrose (Ro et al., 1990). Then, the samples were washed three times with the same buffer $(\mathrm{pH} 7.4)$ and post-fixed in $1 \%$ cacodylate-buffered osmium tetroxide ( $\mathrm{pH} 7.6$ ) containing $5 \%$ sucrose. The samples were "en bloc" stained with $1 \%$ aqueous uranyl acetate (overnight), dehydrated in an ascending acetone series, embedded and included in Epon-Araldite resin. Thin and ultrathin sections were obtained with a Leica UC7 ultramicrotome and contrasted with $2 \%$ uranyl acetate in water for 45 min and $0.4 \%$ lead citrate in $0.1 \mathrm{~N} \mathrm{NaOH}$ for 10 min (Reynolds, 1963; Venable and Coggeshall, 1965). Images were obtained, taken and digitalized using a JEOL - JEM 1010 transmission electron microscope operated with an $80 \mathrm{kV}$ electron beam.

\subsection{Sequences and phylogenetic analysis}

Most of the sequences were generated by us at the Laboratory of Bioecology and Crustacean Systematics (LBSC) following the molecular protocol established by Mantelatto et al. (2007), and are referenced in Table 2. Partial 16S rDNA and COI mtDNA sequences from Dendrobranchiata specimens were deposited in GenBank; the accession numbers are available in Table 2, including the sequences of the six species described here in terms of sperm ultrastructure.
All sequences were aligned for each gene dataset using Clustal W in the BioEdit program (Thompson et al., 1994) and concatenated by Crimson Editor (available http://www.crimsoneditor.com/english/ download.html). In the $16 \mathrm{~S}$ gene alignment, $460 \mathrm{bp}$ are included, and for the COI gene, 547 bp are included. The best-fit model of nucleotide substitution for each gene dataset was calculated using the Akaike information criterion (AIC) and Bayesian information criterion (BIC) by jModeltest (Posada, 2008). The phylogenetic hypothesis was generated based on the concatenated genes and estimated by Bayesian inference (BI) (Huelsenbeck et al., 2001). The data were partitioned by gene and codon positions for COI with separate parameters for each partition in the BI. The analysis was performed in the MrBayes 3.1 program (Huelsenbeck and Ronquist, 2001) configured to use the GTR + G + I model. Each Bayesian search was performed for 2,000,000 generations (sampling every 500) using four chains (default heating parameters) and a $15 \%$ burn-in value. The included Bayesian sets of trees were sampled after the likelihood scores reached convergence and the mean split difference values were less than 0.01 . The levels of branch support were obtained using the posterior probability method. A $50 \%$ majority rule consensus tree was obtained from the remaining saved trees. All saved trees were edited using FigTree (Rambaut, 2009).

\section{Results}

\subsection{Tribe Penaeini}

\subsubsection{Sperm ultrastructure of $F$. brasiliensis}

Sperm of $F$. brasiliensis is dispersed in the secretion at the distal region of the posterior vas deferens without any spermatophore wall (Fig. 1A). The sperm length of $F$. brasiliensis measures approximately $11.90 \pm 1.75 \mu \mathrm{m}(\mathrm{n}=15)$. The longitudinal section of the sperm can be divided into two regions: the acrosomal vesicle, formed by the spike and acrosomal cap, and the main body (Fig. 1B). The spike is long with a smooth surface and is internally composed of bundles of fibrils (Fig. 1C). There is dilation in the base of the spike insertion region of the main body, which forms a cubic electron-dense figure (Fig. 1D). The main body is spherical and displays two projections of the acrosomal cap that move towards the opposite poles of the spike (Fig. 1B, E). The acrosomal cap is filled with moderate electron-dense material (Fig. 1B, D, E). This material completely surrounds the apical region of the main body. The subacrosomal space is slightly concave and there are many

Table 2

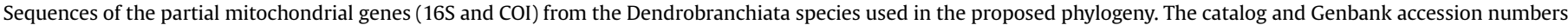
are listed, as well as the authors who sent the sequences to GenBank.

\begin{tabular}{|c|c|c|c|c|c|}
\hline Species & $\begin{array}{l}\text { Specimen } \\
\text { voucher } 16 S\end{array}$ & $\begin{array}{l}\text { GenBank } \\
16 S\end{array}$ & $\begin{array}{l}\text { Specimen } \\
\text { voucher COI }\end{array}$ & $\begin{array}{l}\text { GenBank } \\
\text { COI }\end{array}$ & Authors \\
\hline Farfantepenaeus brasiliensis (1) & VI063 Fbra_BSE & HМ014403 & CCDB 4532:84 & KF989423 & Bremer et al., 2010; Teodoro et al., 2016 \\
\hline Farfantepenaeus brasiliensis (2) & VI062 Fbra_BSE & HM014402 & CCDB 4532:55 & KF989421 & Bremer et al., 2010; Teodoro et al., 2016 \\
\hline Farfantepenaeus paulensis & - & AF192057 & CCDB 4679 & KF989461 & Maggioni et al., 2001; Teodoro et al., 2016 \\
\hline Farfantepenaeus subtilis & - & AF192061 & CCDB 4717 & KF989462 & Maggioni et al., 2001; Teodoro et al., 2016 \\
\hline Litopenaeus schmitti & - & AF192082 & CCDB 3457 & KX196596 & Maggioni et al., 2001; Rossi, 2016 \\
\hline Litopenaeus vannamei (1) & - & AY264914 & - & AY781297 & Quan et al., 2004; Zheng et al., 2005 \\
\hline Litopenaeus vannamei (2) & Lvan03 BSE & HM014412 & - & JN165705 & Bremer et al., 2010; Badhul et al., unpublished \\
\hline Parapenaeus americanus (1) & MNHN IU_2014- 4028 & КР059267 & MNHN IU-2014-4028 & КР072655 & Yang et al., 2015 \\
\hline Parapenaeus americanus (2) & CCDB 5827 & KX196539 & CCDB 5827 & KX196597 & Rossi, 2016 \\
\hline Penaeopsis serrata & BATO 054(EPC) & AY601733 & FCFOPC050-01 & JQ306266 & Vazquez-Bader et al., 2004; Matzen-da-Silva et al., 2011 \\
\hline Rimapenaeus constrictus & CCDB 3639 & KF783863 & - & AY622212 & Chan et al., 2008; Carvalho-Batista et al., 2014 \\
\hline Sicyonia dorsalis & UCR 2469-02 & KX196478 & UCR 2469-02 & KX196550 & Rossi, 2016 \\
\hline Sicyonia typica & CCDB 341 & KT935434 & CCDB 341 & KX196577 & Camargo et al., 2016; Rossi, 2016 \\
\hline Xiphopenaeus kroyeri & - & AF192090 & CCDB5018 & KX196599 & Maggioni et al., 2001; Rossi, 2016 \\
\hline Acetes americanus & CCDB 4939 & KX196538 & CCDB 4939 & KX196595 & Rossi, 2016 \\
\hline Peisos petrunkevitchi & CCDB 4940 & KX196540 & CCDB 4940 & KX196598 & Rossi, 2016 \\
\hline Sergia robusta & - & - & JSDPX79-05 & JQ306179 & Matzen-da-Silva et al., 2011 \\
\hline
\end{tabular}



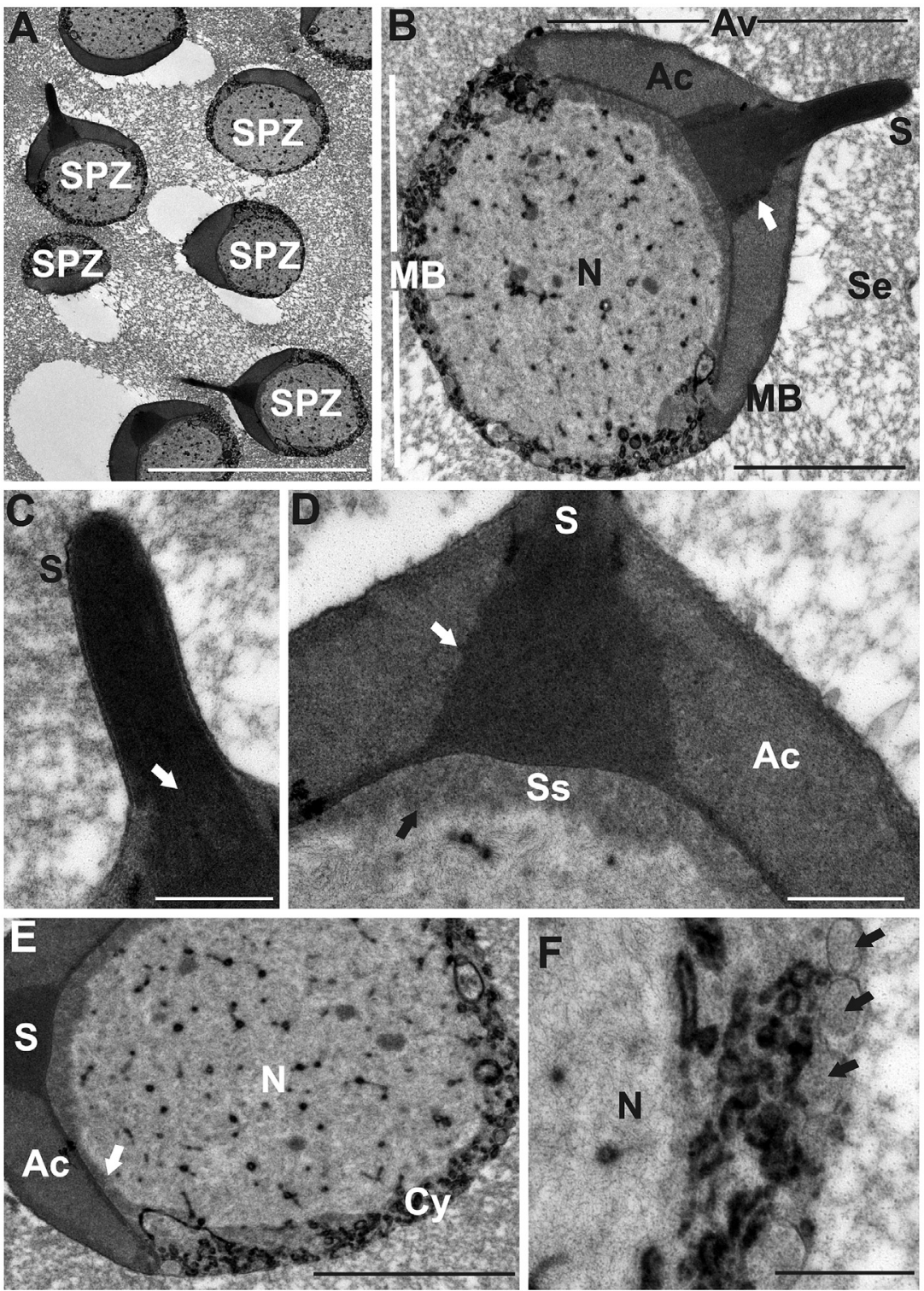

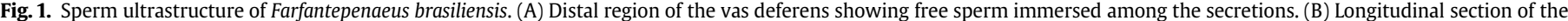

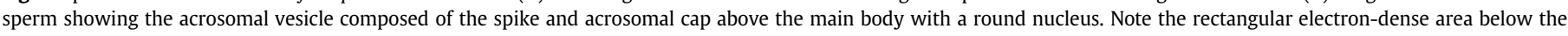

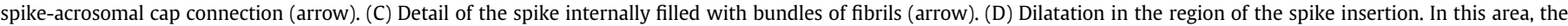

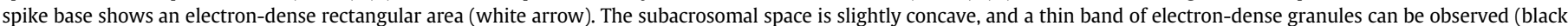

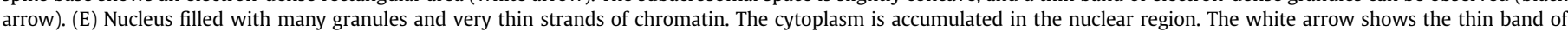

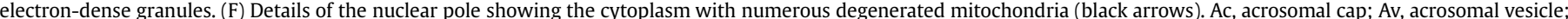

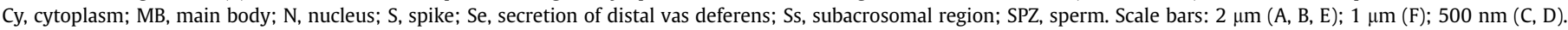

electron-dense granules beneath the spike (Fig. 1D). The main body is marked by the presence of the bulky central nucleus filled with granular chromatin and some fibrous elements (Fig. 1E). The main part of the cytoplasm is found on the nuclear pole (opposite the spike) and is filled with membranous organelles resembling degenerated mitochondria (Fig. 1F).

\subsubsection{Sperm ultrastructure of F. paulensis}

Similar to the sperm of $F$. brasiliensis, the sperm of $F$. paulensis are free in the secretion of the distal vas deferens and are not enclosed by a spermatophore wall. The sperm length is approximately $10.00 \pm 1.41 \mu \mathrm{m}(\mathrm{n}=8)$. The longitudinal section shows the main body and the acrosomal vesicle, which consists of the acrosomal cap and spike (Fig. 2A). The base of the spike is internal to the main body, and there is also a dilatation of its base forming a triangular electron-dense figure (Fig. 2B). The main body is spherical, and the acrosomal cap runs toward the opposite pole of the spike and ends at the equator of the main body (Fig. 2A). The nucleus is composed of bulky and granular chromatin and slender filaments (Fig. 2A). The subacrosomal space is also slightly concave and contains electron-dense granules (Fig. 2B). The cytoplasm, which is also concentrated in the nuclear pole, contains many degenerated mitochondria and electron-dense granules (Fig. 2C).

\subsubsection{Sperm ultrastructure of L. schmitti}

The sperm of $L$. schmitti is free in the secretion of the distal vas deferens. In the longitudinal section, the sperm consists of the acrosomal cap and long spike, and both together form the 

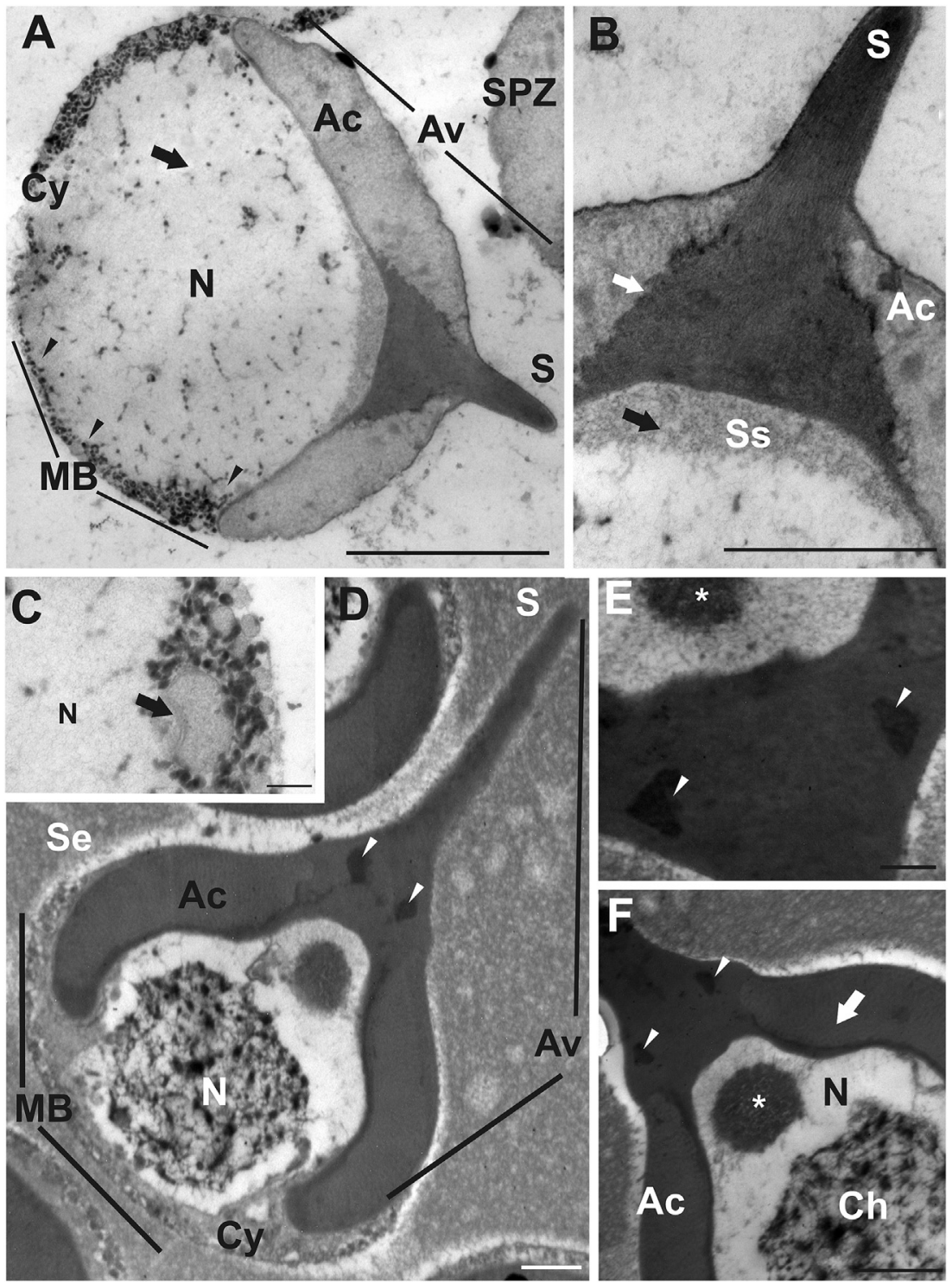

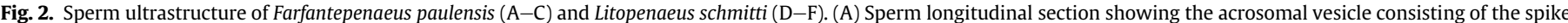

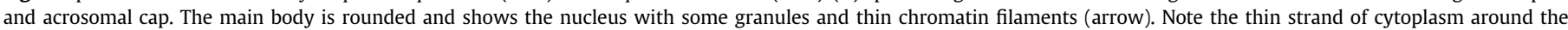

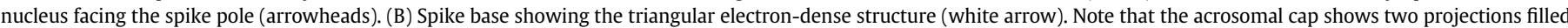

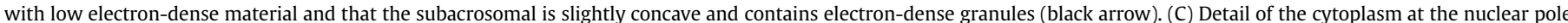

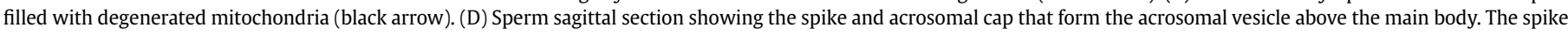

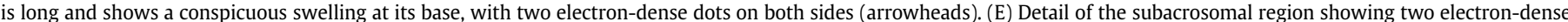

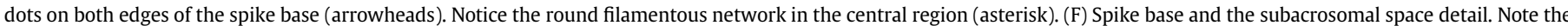

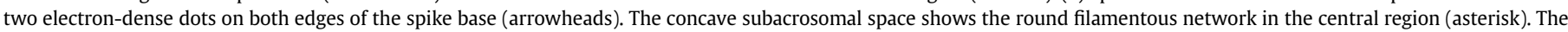

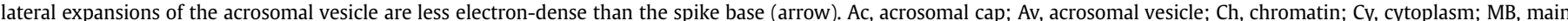
body; N, nucleus; S, spike; Se, secretion of distal vas deferens; Ss, subacrosomal region; SPZ, sperm. Scale bars: $2 \mu \mathrm{m}$ (A); $1000 \mathrm{~nm}$ (B); $200 \mathrm{~nm}$ (C); $500 \mathrm{~nm}$ (D, E, F).

acrosomal vesicle (Fig. 2D). The sperm measurements are approximately $11.06 \pm 1.66 \mu \mathrm{m}(\mathrm{n}=15)$, and the main body is spherical (Fig. 2D). The main body shows the nucleus and the thin cytoplasm forming the nuclear pole in opposition to the spike (Fig. 2D). The base of a spike is enlarged and shows two electron-dense dots at the edge of this spike region (Fig. 2D-F). The subacrosomal region is concave, and a filamentous network can be observed in the center (Fig. 2D-F). The subacrosomal space and chromatin are separated by an electron-lucent space (Fig. 2F). Then, the acrosomal cap forms lateral expansions on both sides of the main body that cover $2 / 3$ of the main body (Fig. 2D). The round nucleus is located in the central part of the main body and shows filamentous chromatin with several electron-dense granules dispersed in the nucleoplasm (Fig. 2D, F). The cytoplasm is small and concentrated in the nuclear pole opposite the spike (Fig. 2D).

\subsection{Tribe Parapenaeini}

\subsubsection{Sperm ultrastructure of $P$. americanus}

The sperm of $P$. americanus is free in the secretions of the distal vas deferens. The spermatozoa length measures $9.00 \pm 1.20 \mu \mathrm{m}$ $(n=6)$. The main body is spheroidal, and the longitudinal sections, show the central nucleus and acrosomal vesicle formed by the acrosomal cap and a thin spike (Fig. 3A). The spike is long 

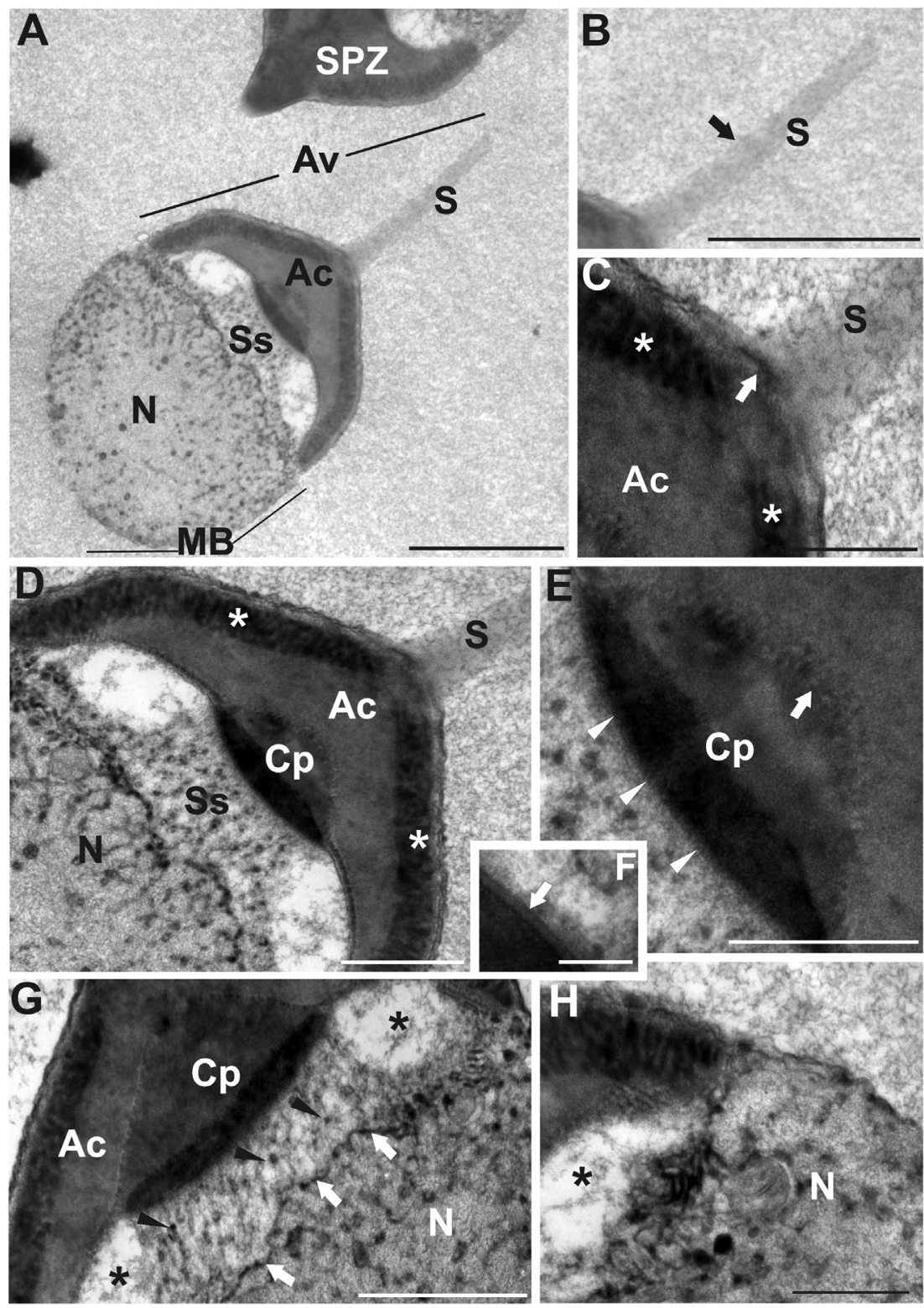

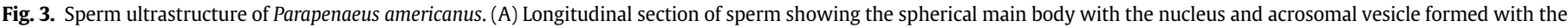

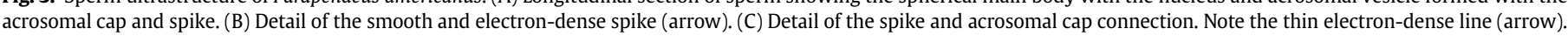

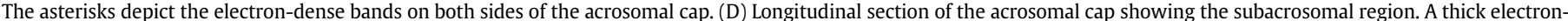

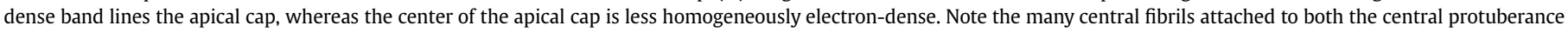

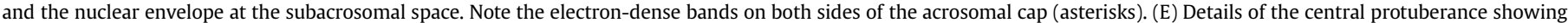

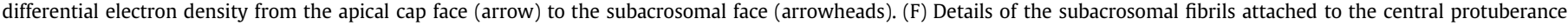

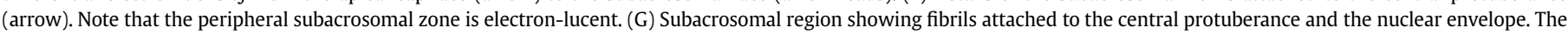

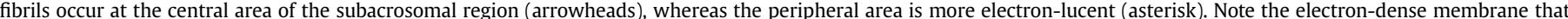

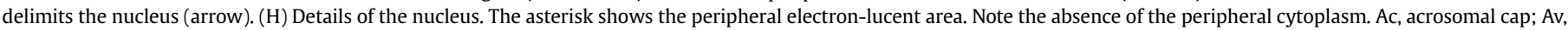

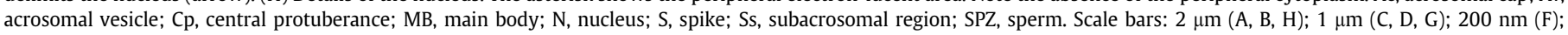
$500 \mathrm{~nm}(\mathrm{E})$.

(Fig. 3A-C), and there is a thin electron-dense band in the spike insertion of the main body that connects the spike to the acrosomal cap (Fig. 3C). The acrosomal cap is wide and shows two lateral projections from the base of the spike covering $1 / 3$ of the main body above the subacrosomal space of the spermatozoa (Fig. 3A, D). On each side of the apical cap, there is a thick band of electrondense material turned to the spike pole lined on the apical cap, whereas the center of the apical cap is reduced and homogeneously electron-dense (Fig. 3C and D). The acrosomal cap shows a central protuberance facing the wide subacrosomal space (Fig. 3A, C, D).
This central protuberance shows that the spike face is less electrondense, whereas the nuclear face, which is turned to the subacrosomal space, is electron-dense; both faces are rounded (Fig. 3D and $\mathrm{E}$ ). The nuclear face of the central protuberance is less electrondense; many fibrils are attached to it and extend to the disrupted nuclear envelope (Fig. 3F). These fibrils occupy the central part of the subacrosomal space, whereas the peripheral zone of the subacrosomal space is electron-lucent and shows few materials (Fig. 3E-G). The nucleus is filled with chromatin and granular material (Fig. 3H). 


\subsection{Tribe Trachypenaeini}

\subsubsection{Sperm ultrastructure of $R$. constrictus}

Sperm of $R$. constrictus is compacted inside a spermatophoric structure composed of a matrix surrounded by an electron-dense wall (Fig. 4A). The sperm measurement is approximately $13.03 \pm 1.55 \mu \mathrm{m}(\mathrm{n}=10)$ in length. These cells are very complex and show a fusiform-elongated main body divided into a nuclear area, which is covered by the acrosomal cap, and a posterior elongated region (Fig. 4B). The acrosomal vesicle is formed by a long eccentric spike and the acrosomal cap (Fig. $4 \mathrm{~B}$ ). The spike is very long and consists of bundles of fibrils attached to the acrosomal cap in a parallel angle marked with an electron-dense area inserted into the electron-dense central part of the acrosomal cap (Fig. 4C and D). The acrosomal cap shows an electron-lucent area and then becomes very thin and slightly electron-dense running to the posterior elongated region covering the nuclear region (Fig. 4D-F). The posterior margin of the acrosomal cap ends as a round margin close to the cytoplasmic organelles of the posterior elongated region (Fig. 4E and F). The subacrosomal region is filled with granular material that is connected to the nuclear envelope and the acrosome cap, forming a slightly striated plate observed in both the
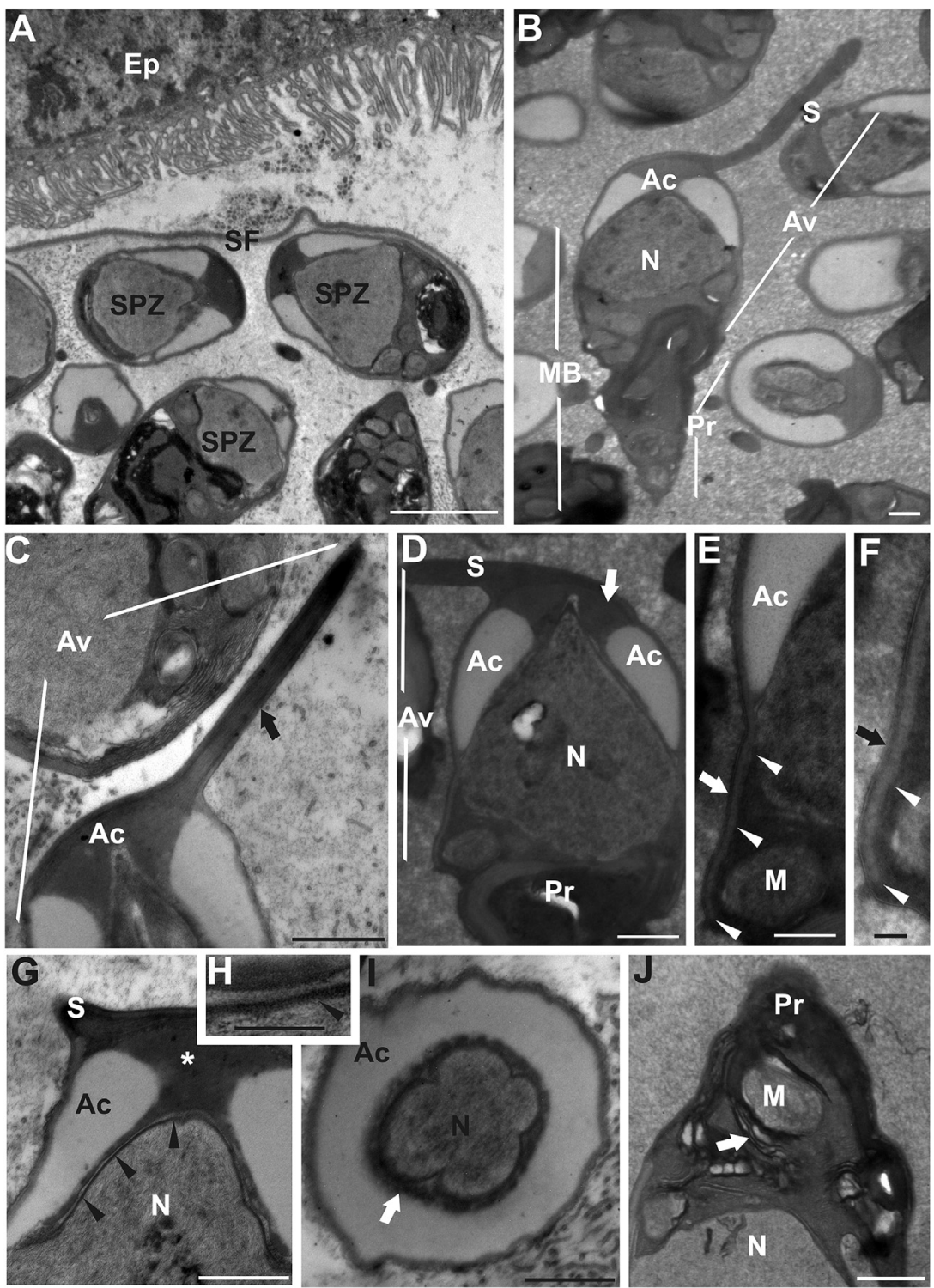

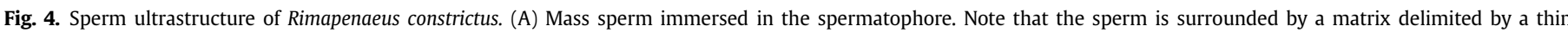

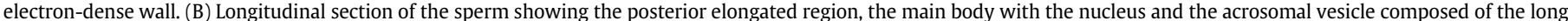

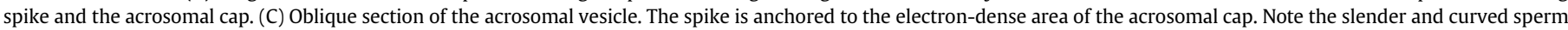

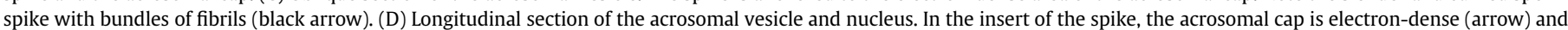

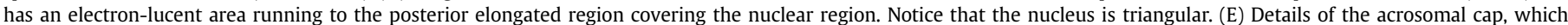

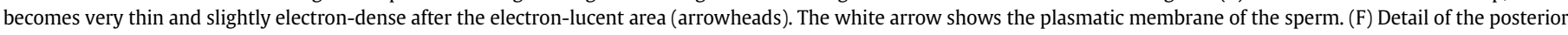

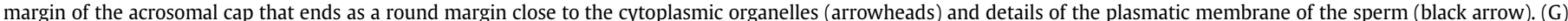

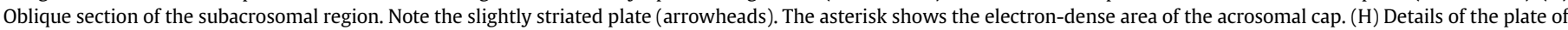

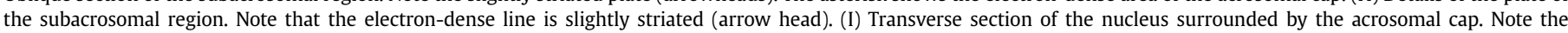

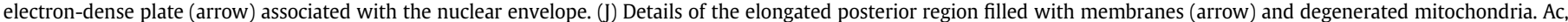

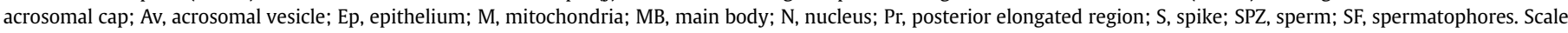
bars: $2 \mu \mathrm{m}(\mathrm{A}) ; 100 \mathrm{~nm}(\mathrm{D}, \mathrm{I}, \mathrm{J}) ; 500 \mathrm{~nm}$ (B, C, E, F, G, H). 
longitudinal and transverse sections (Fig. 4G, H, I). The nucleus is filled with thin chromatin, and the nuclear shape is slightly triangular in the area facing the spike region and rounded to the face turned to the posterior elongated region (Fig. 4B, D, G, I). However, in the transverse sections, the nucleus shows four round lobes, and the electron-dense and thin striated plate is associated with the continuous nuclear envelope (Fig. $4 \mathrm{H}$ ). The posterior elongated region is conical and shows a complex of membranes and degenerated mitochondria extending to the nuclear main body (Fig. 4B, J).

\subsubsection{Sperm ultrastructure of $X$. kroyeri}

Sperm of $X$. kroyeri is enclosed in a spermatophoric structure surrounded by a thick electron-dense wall (Fig. 5A). The sperm length measurements are approximately $13.5 \pm 1.09 \mu \mathrm{m}(\mathrm{n}=10)$ and show an elongated and fusiform main body (Fig. 5B). The main body is also divided into the nuclear area and posterior elongated area (Fig. 5B). The nucleus is almost covered by the acrosomal vesicle, which shows the acrosomal cap and a long spike (Fig. 5C). The spike is filled with bundles of filaments and is inserted in parallel in contact to the electron-dense area of the acrosomal cap (Fig. 5C). The acrosomal cap is enlarged in the spike pole, which is the electron-dense area, and becomes thinner and less electrondense running down to the posterior elongated region covering the main part of the nuclear area (Fig. 5D). The acrosomal cap ends as a round margin without reaching the posterior elongated region (Fig. 5E). The subacrosomal region connects the nuclear envelope to
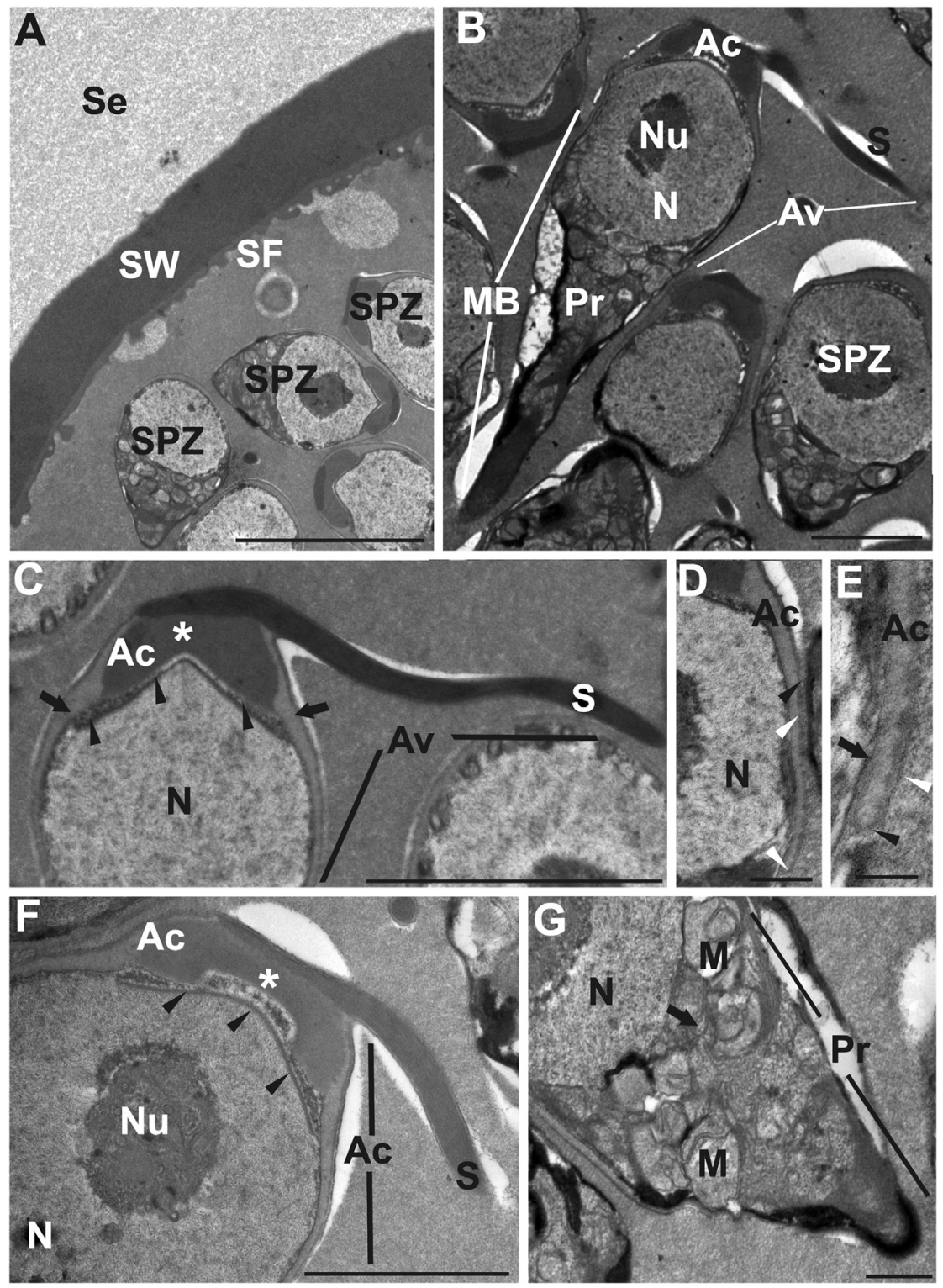

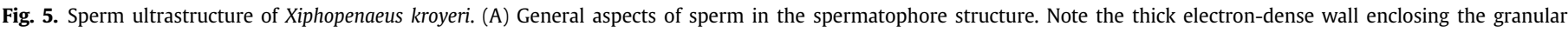

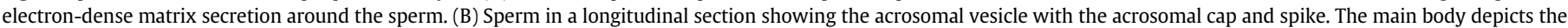

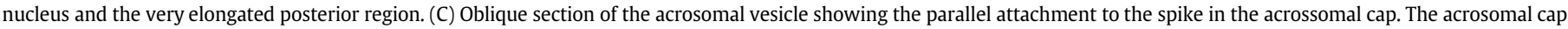

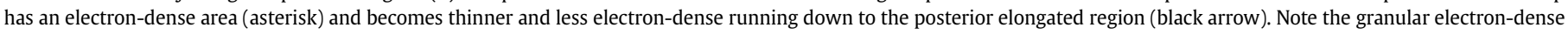

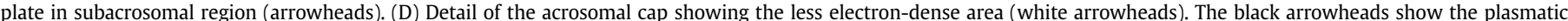

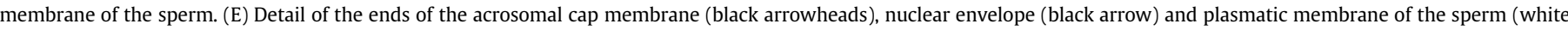

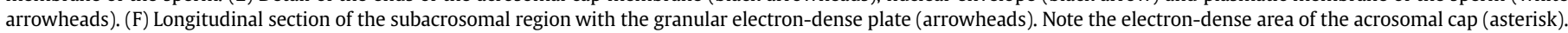

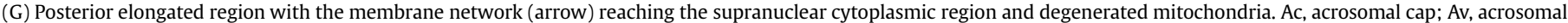

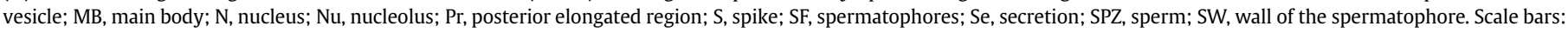
$2 \mu \mathrm{m}$ (A, B, F); 0,5 $\mu \mathrm{m}$ (C, E); $500 \mu \mathrm{m}$ (D, G). 
the acrosome cap through a thin granular electron-dense plate, which is the only material found in the subacrosomal space (Fig. 5C, F). The nucleus is round and filled with fibrous chromatin and a well and large developed central nucleolus (Fig. 5B, F). The elongated posterior region is rich in a complex network of membranes and many degenerated mitochondria (Fig. 5G).

\subsection{DNA analysis}

In total, 33 sequences of 27 Dendrobranchiata specimens were retrieved from GenBank (Table 2). Among them, 24 sequences were from members of the three tribes of Penaeidae (Parapenaeini, Penaeini and Trachypenaeini). Our dataset included $1007 \mathrm{bp}$ of two mitochondrial genes, 460 bp of the partial $16 \mathrm{~S}$ gene and $547 \mathrm{bp}$ of the partial COI gene. The best models chosen for each alignment were: GTR + I + G and HKY + I + G for AIC and BIC, respectively.

The phylogenetic tree was based on concatenated data and tested by Bayesian inference, which showed a good phylogenetic signal. Generally, the branches received high posterior probabilities, and the tribes were positioned in different clades. Clade Penaeini showed that F. paulensis nested F. brasiliensis (99.97\%) and the sister group of species from the genus Litopenaeus (L. vannamei and $L$. schmitti). Representatives of Sicyoniidae appeared in the same clade as members from Trachypenaeini (58.86\%), and this clade was the sister group of the Parapenaeini (93.5\%). The clade of the latter tribe received high posterior probabilities (99.83\%) (Fig. 6).
The tree was rooted with the species of family Sergestidae (99.70\%), as was suggested by Scelzo and Medina (2004) and Medina et al. (2006a, b). Therefore, we added sequences of the Acetes americanus Ortmann, 1893, Peisos petrunkevitchi Burkenroad, 1945 and Sergia robusta (Smith, 1882) to act as outgroups (Fig. 6).

\section{Discussion}

The description of the sperm ultrastructure for the six shrimps that occur on the Brazilian coast is enlightening in terms of understanding the relationships among the phylogeny of the Penaeidae. Additionally, the sperm ultrastructure of the tribe Trachypenaeini species was presented for the first time for both $R$. constrictus and X. kroyeri. Individuals of Penaeidae showed sperm with a round main body, usually filled with the nucleus, and acrosomal vesicles that included the acrosomal cap and spike (Jamieson, 1991; Medina et al., 1994a, b; Medina, 1995; Jamieson and Tudge, 2000; Tudge, 2009; Braga et al., 2013a, b). However, we found some variations in the sperm ultrastructure according to the tribe (Fig. 7 and Table 3). The main difference among the members of the tribes was the main body morphology.

The members of Penaeini showed sperm with a spherical main body, whereas the sperm were bulged in Parapenaeini and elongated in Trachypenaeini (Bauer and Min, 1993; Medina et al., 1994a, b; Alfaro et al., 2003; Scelzo and Medina, 2003; Braga et al., 2013a). As previously described, a spherical main body was found in the

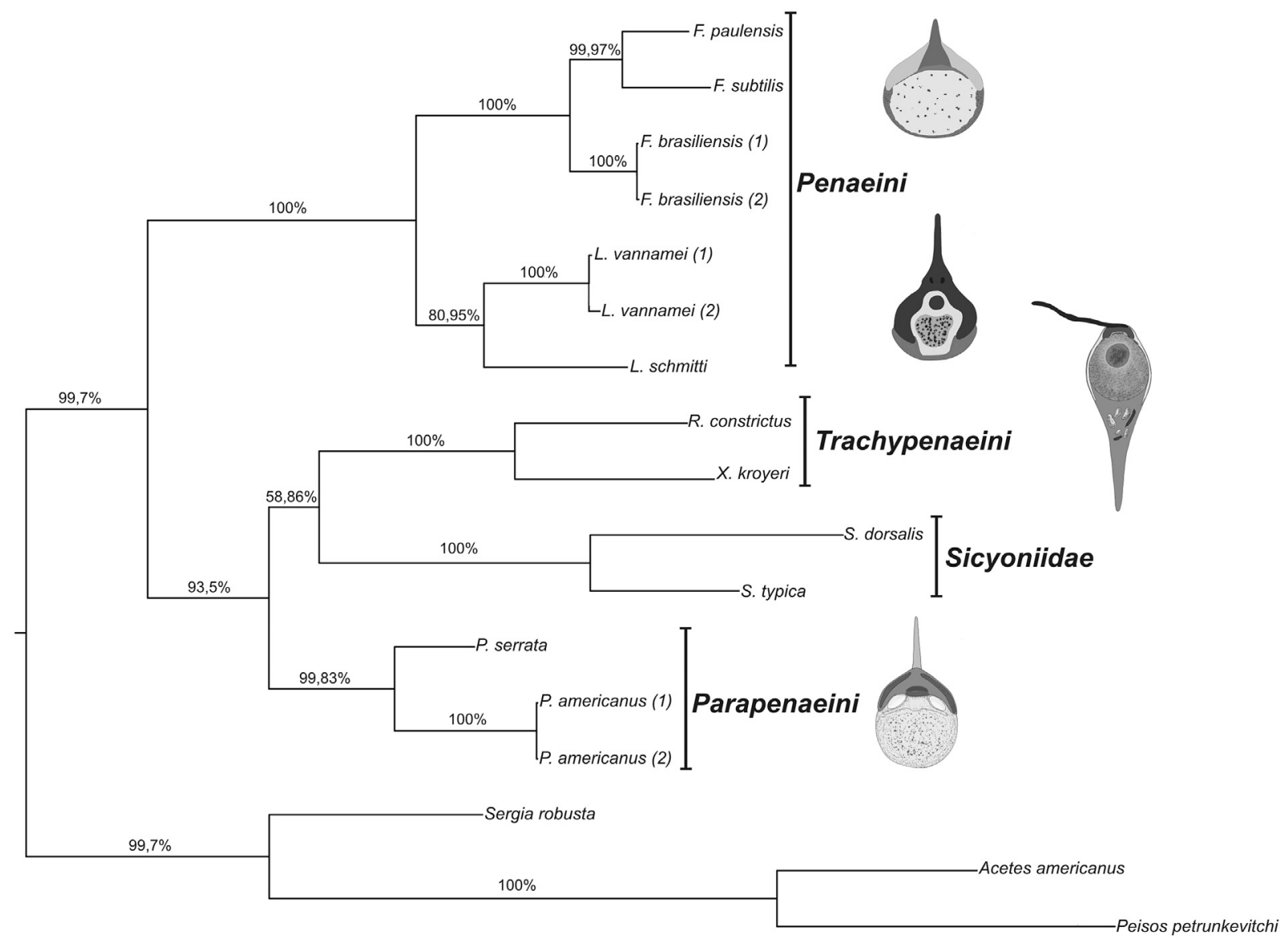

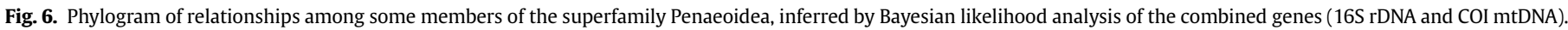

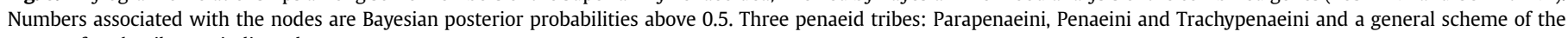
sperm of each tribe are indicated. 


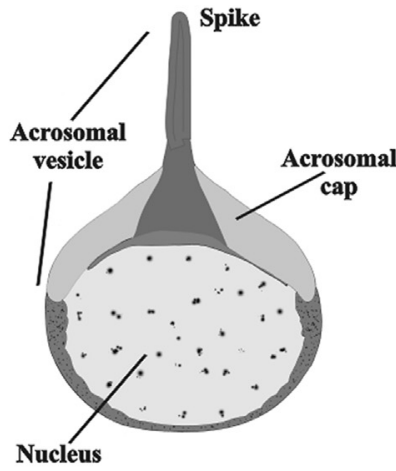

Penaeini

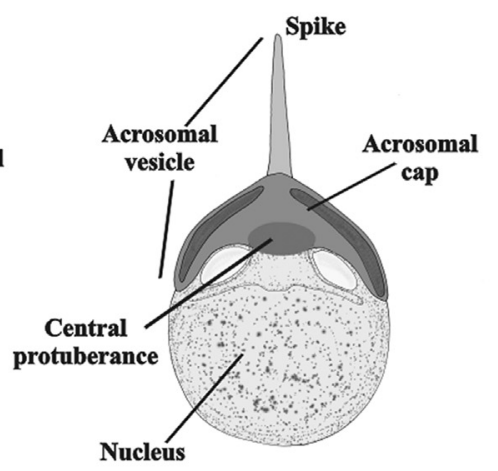

Parapenaeini

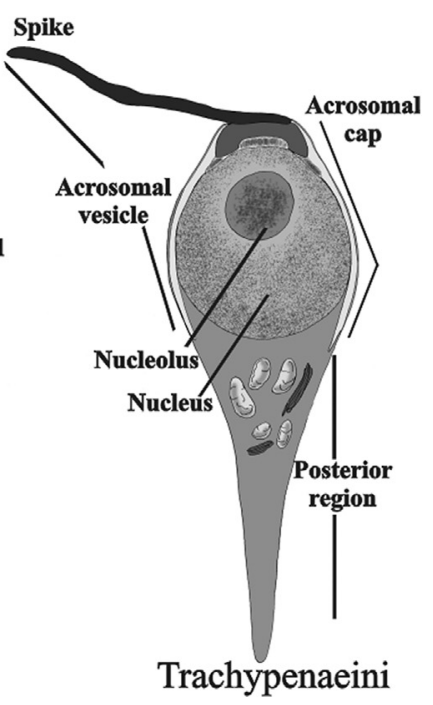

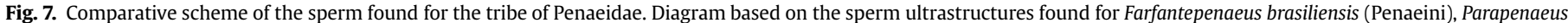
americanus (Parapenaeini) and Xiphopenaeus kroyeri (Trachypenaeini).

Table 3

Comparative sperm ultrastructural traits of three tribes of the Penaeidae family.

\begin{tabular}{llll}
\hline Characteristic & Penaeini & Parapenaeini & Trachypenaeini $^{\text {Prosomal cap }}$ \\
\hline Acrosomal protuberance & Short $^{\mathrm{a}}$ & Short $^{\mathrm{a}}$ & Elongated $^{\mathrm{b}}$ \\
Central & Absent $^{\mathrm{a}}$ & Present $^{\mathrm{b}}$ & Absent $^{\mathrm{a}}$ \\
Electron-dense plate & Absent $^{\mathrm{a}}$ & Absent $^{\mathrm{a}}$ & Present $^{\mathrm{b}}$ \\
Main body & Round $^{\mathrm{a}}$ & Spheroidal $^{\mathrm{a}}$ & Elongated $^{\mathrm{b}}$ \\
Posterior elongated region & Absent $^{\mathrm{a}}$ & Absent $^{\mathrm{a}}$ & Present $^{\mathrm{b}}$ \\
Spike & Straight $^{\mathrm{a}}$ & Straight $^{\mathrm{a}}$ & Curved $^{\mathrm{b}}$ \\
Spermatophore & Absent $^{\mathrm{a}}$ & Absent $^{\mathrm{a}}$ & Present $^{\mathrm{b}}$ \\
Sperm morphology & Round $^{\mathrm{a}}$ & Round $^{\mathrm{a}}$ & Elongated $^{\mathrm{b}}$ \\
\hline
\end{tabular}

a Plesiomorphic characteristic

b Apomorphic characteristic.

tribe Penaeini species analyzed in our study ( $F$. brasiliensis, F. paulensis and $L$. schmitti). The same rounded pattern was observed in other species of the tribe, such as Farfantepenaeus aztecus (Ives, 1891) (Clark et al., 1973 as Penaeus aztecus), Litopenaeus occidentalis (Streets, 1871), L. stylirostris (Stimpson, 1871), L. vannamei (Boone, 1931) (Clark et al., 1973; Alfaro et al., 2007), Melicertus kerathurus (Forskal, 1175) (Medina et al., 1994a as Penaeus kerathurus), Penaeus monodon Fabricius, 1798 and Marsupenaeus japonicus (Spence Bate, 1888) (Medina et al., 1994a as Penaeus japonicus) (Clark et al., 1973; Medina et al., 1994a; Alfaro et al., 2007; Kruevaisayawan et al., 2008). Scanning electron microscopy studies also described the spherical main body of Farfantepenaeus duorarum (Burkenroad, 1939) (Bauer and Cash, 1991 as Penaeus duorarum) and F. subtilis (Pérez-Farfante, 1967) (Bauer and Cash, 1991; Castelo-Branco et al., 2014). Furthermore, the spherical morphology of the F. paulensis and L. schmitti spermatozoa corroborated the descriptions reported by Braga et al. (2013b) and Fransozo et al. (2016), respectively.

According to the literature, members from the tribe Parapenaeini present a bulged main body instead of the regularly spherical body observed in Parapenaeus longirostris (Lucas, 1846) and Penaeopsis serrata Spence Bate, 1881 (Medina, 1994; Medina et al., 1994b; Scelzo and Medina, 2003; Braga et al., 2013a). However, in our analysis, we observed that $P$. americanus had a spheroidal main body similar to that observed in Artemesia longinaris Spence Bate, 1888 (Scelzo and Medina, 2003).

Moreover, the species of the tribe Trachypenaeini analyzed here, such as $R$. constrictus and $X$. kroyeri, had an elongated main body similar to observations in other representatives of the group, including Xiphopenaeus riveti (Heller, 1862) (Alfaro et al., 2003 as X. kroyeri), Rimapenaeus similis (Smith, 1885) (Bauer and Min, 1993 as Trachypenaeus similis) and Rimapenaeus byrdi (Burkenroad, 1934) (Alfaro et al., 2003 as Trachypenaeus byrdi), based on scanning electron microscopy (Bauer and Min, 1993; Alfaro et al., 2003).

The rounded main body of the sperm is considered a plesiomorphic characteristic (Medina et al., 1994a, b; Scelzo and Medina, 2003; Ma et al., 2009; Braga et al., 2013a). Therefore, a diversification of the main body shape within the Penaeidae would be a basal condition. This characteristic is found in individuals of the tribe Penaeini (Braga et al., 2013a), whereas members of the Parapenaeini show sperm with a spheroidal main body and shrimp of the Trachypenaeini have an elongated main body (Medina et al., 1994a, b; Scelzo and Medina, 2003; Braga et al., 2013a). Thus, the elongated main body could be considered an apomorphic status in shrimp from Trachypenaeini (Ma et al., 2009; Braga et al., 2013a).

The sperm of members of the tribe Penaeini are characterized by the acrosomal cap overlaying the main body. Additionally, the subacrosomal space is concave and simpler compared to the other tribes. Individuals from Penaeini show free sperm in the secretions from the vas deferens. The sperm is only packaged in the spermatophore when expelled from the male in the terminal ampoule (Bauer, 1991). Species of Parapenaeini and Penaeini also show free sperm in vas deferens secretions. The synapomorphy of the Parapenaeini is the central protuberance at the base of the acrosomal cap of the sperm, as was observed in other species of the tribe described in the literature ( $P$. longirostris, $P$. serrata and A. longinaris) (Medina, 1994; Medina et al., 1994b; Scelzo and Medina, 2003, 2004; Braga et al., 2013a) and confirmed here in P. americanus. Thus, our ultrastructural findings suggest the validity of tribe Parapenaeini as argued earlier by Medina (1995) and Scelzo and Medina (2003).

Similarly, the sperm of individuals of the tribe Trachypenaeini showed a main body with a posterior elongated region, which was very complex and was formed by many membranes and degenerate mitochondria. Additionally, the sperm present a very filamentous and slender spike, which is curved, and a very thin acrossomal cap running to the posterior elongated region covering the nuclear region, which can be considered a synapomorphy of the Trachypenaeini. The slender and curved spike was described using scanning electron microscopy for the first time by Bauer and 
Min (1993) as a thin structure called the filament. However, Alfaro et al. (2003) described the same structure and called it the spike. Following its description for the first time at the ultrastructural level, the region of the spermatozoa of Trachypenaeini considered the filament by Bauer and Min (1993) was called the spike in this study due to the presence of the acrosomal cap with vesicles in the area of the spike insertion; this morphology is typical for the Dendrobranchiata shrimp. Thus, the spike described in this study is synonymous to the filament described for $R$. similis (Bauer and Min, 1993 as T. similis) (Bauer and Min, 1993).

The nucleus shows an electron-dense plate connected to the acrosomal cap surrounded by a continuous nuclear envelope, which is different from all other Penaeidae (Medina et al., 1994a, b; Jamieson and Tudge, 2000; Braga et al., 2013a, b) and at the same time similar to the structure found for the family Sicyoniidae (Kleve et al., 1980; Medina, 1995; Camargo et al., 2016). Another synapomorphy found in the tribe Trachypenaeini is that the sperm is packed in spermatophores similar to those found in Brachyura (Bauer and Min, 1993). The same pattern of sperm encapsulated by spermatophores was described based on scanning electron microscopy in other representatives of the group, such as $X$. kroyeri (Alfaro et al., 2003 as X. riveti), R. similis (Bauer and Min, 1993 as T. similis) and $R$. byrdi (Alfaro et al., 2003 as T. byrdi) (Bauer and Min, 1993; Alfaro et al., 2003).

Although we found some common characteristics among species of the same tribe, we also detected characteristics unique to each genus in this study. Thus, the different acrosomal cap structure may represent an autapomorphy for each genus of the tribe. The genera of the genus Litopenaeus and Farfantepenaeus, showed differences in the acrosomal cap despite their proximity. The species of Litopenaeus presented an acrosomal cap that occupied twothirds of the main body, with condensation of the acrosomal content in the cytoplasmic face to, form lateral extensions on both sides of the main body. Moreover, these species showed the filamentous network found in the subacrosomal region, as observed in L. schmitti, L. vannamei, L. stylirostris and L. occidentalis, which is a synapomorphy of the genus (Dougherty and Dougherty, 1989; Alfaro et al., 2007). However, the circular filamentous network found in the subacrosomal space was exclusive to L. schmitti.

Species of the Farfantepenaeus genus present two projections of the acrosomal vesicle in the main body but do not overlap most of the cytoplasmic face, as observed in the species of Litopenaeus. The round nucleus is at the opposite pole of the spike, and the cytoplasm is filled with vesicles, which confirm the description assigned to F. paulensis (Braga et al., 2013b). Despite the similarities between the $F$. paulensis and $F$. brasiliensis species, the main difference found was the presence of electron-dense material in the central region of the acrosomal cap, which was triangular in F. paulensis and cubic in F. brasiliensis. According to Braga et al. (2013b), large vesicles were not found in the cytoplasm in F. brasiliensis, and only small vesicles were observed; this finding differed from $F$. paulensis, which exhibits that depicts two types of vesicles in the cytoplasm. The presence of large or small vesicles represented degenerated organelles, such as mitochondria (Tudge, 2009). However, these vesicles finding cannot be considered a robust characteristic among species because they can vary from sperm to sperm. Furthermore, in F. brasiliensis, morphological differences were observed between the sperm stored in the thelycum and the sperm found in the terminal ampoule (Braga et al., 2014).

The sperm stored in the thelycum had a less concave acrosomal cap and a more electron-dense subacrosomal region (Braga et al., 2014). However, in this study, the sperm collected in the distal vas deferens had the same morphology as those stored in the thelycum, as observed by Braga et al. (2014). In our opinion, the final morphology of the mature sperm in Farfantepenaeus is reached in the distal vas deferens immediately before the terminal ampoule. In our material, the ampoule of both congener species of Farfantepenaeus showed an absence of sperm. The triangular region in the central part of the acrosomal cap and the general appearance of the acrosomal vesicle of $F$. paulensis is very similar to reports for M. japonicus (Medina et al., 1994a as Penaeus japonicus), with the exception of the membrane in the subacrosomal region of this latter species (Medina et al., 1994a). To summarize, our findings of the sperm ultrastructure support the phylogenetic proximity of both the F. paulensis and $F$. brasiliensis species and species of the genus Litopenaeus. These shrimp also share a complex form of spermatophore despite the lack of some morphological structures, such as wings, in Farfantepenaeus (Bauer and Cash, 1991; PérezFarfante and Kensley, 1997).

Artemesia longinaris and $P$. serrata have a similar morphology of the acrosomal cap and cytoplasm, and the central protuberance of both of species is rounded and salient (Medina, 1994; Medina et al., 1994b; Scelzo and Medina, 2003). Additionally, A. longinaris has a spheroidal main body, whereas the main body is not regular in P. serrata (Medina et al., 1994b; Scelzo and Medina, 2003). Parapenaeus americanus and P. longirostris have a flatter central protuberance, but the configuration of the acrosomal cap is different. In P. longirostris, the acrosomal cap is shorter, the lateral projections are thicker, and the spike is more robust, particularly the insertion of the acrosomal cap. Conversely, P. americanus has thinner lateral projections, and the spike is slender, whereas the main body is rounded with a rather bulky nucleus.

The configuration of the acrosomal cap and the morphology of the sperm nucleus are different between the two species Trachypenaeini studied in the present work. In $R$. constrictus, the acrosomal cap has a central area, which is the electron-lucent vesicle surrounding $1 / 2$ of the nuclear surface. The nuclear shape is slightly triangular in the area facing the spike region and rounded in the area facing the posterior elongated region. In contrast, in $X$. kroyeri, the acrosomal cap shows a central core granule similar to a figure in the shape of an inverted " $U$ ", and two thin vesicles formed by moderated electron-dense material can be observed on the external edges running above $1 / 3$ of the spike pole of the nucleus. The nucleus is round and filled with thin chromatin and a large central nucleolus is found.

The tribes suggested by Burkenroad (1983) were based on the morphology external to the members of each group. Our findings showed that there were also differences in the sperm ultrastructure. These results are in agreement with previous molecular phylogenetic hypotheses (Ma et al., 2009; present study). Inside the evolutionary lineage of the Penaeid-like shrimp, the tribe Penaeini is in a separate branch from the other two tribes. This tribe could be considered the most well-established tribe. Members from the tribe Parapenaeini should have diversified from the same ancestor as the tribe Trachypenaeini and Sicyonia genus. The tribe Trachypenaeini was considered the most derived and underwent late diversification compared to the other tribes (Ma et al., 2009; Braga et al., 2013a). These results corroborate our morphological analysis because the sperm from the tribe Penaeini has the simplest pattern; moreover the presence of the main body is rounded, and the subacrosomal region is simple, which can be considered plesiomorphic characteristics (Ma et al., 2009; Braga et al., 2013a). Additionally, the tribe Trachypenaeini has large and complex sperm with an elongated posterior main body, a very thin acrosomal cap running to the posterior elongated region, a nuclear plate, a continuous nuclear envelope and a very distinctive spike, which is quite different from the morphological pattern observed in the Penaeid-like lineage shrimp (Ma et al., 2009; Braga et al., 2013a, b).

In the molecular phylogenetic hypotheses of our group and Ma et al. (2009), the family Penaeidae seems to be paraphyletic because 
representatives from other families belonging to the superfamily Penaeoidea are closely related. Moreover, this finding can be observed in our morphological analysis, because the members of the tribe Trachypenaeini have sperm with a large cytoplasmic complexity, which is also found in species of Sicyoniidae (Kleve et al., 1980; Medina et al., 1994a, b; Ma et al., 2009; Braga et al., 2013a; Camargo et al., 2016).

According to Bauer (1991), the complex spermatophore and open thelycum can be associated with a primitive condition. However, species of the genus Farfantepenaeus show a complex spermatophore and closed thelycum (Bauer and Min, 1993; PérezFarfante and Kensley, 1997). The derived condition is the closed thelycum and simple sperm masses, as described in shrimp of the genus Sicyonia and from the tribe Trachypenaeini (Pérez-Farfante and Kensley, 1997). Moreover, species of Rimapenaeus and Xiphopenaeus are considered to have an intermediate degree of the spermatophore structure with round spermatophores immersed in adhesive seminal fluid (Bauer and Cash, 1991; Bauer and Min, 1993). Thus, the closed thelycum, spermatophores and the sperm ultrastructure can be additional characteristics to support the proximity between the two groups, thereby corroborating the molecular phylogeny proposed here and by Ma et al. (2009).

In conclusion, there are extraordinary differences among the sperm of the members of the penaeid tribes that could be related to the paraphyletic pattern of this group. As suggested by Ma et al. (2009), these tribes could be treated as having the same taxonomic rank as Sicyoniidae. Moreover, some our findings confirmed the relationships among the tribes and other shrimp of the Penaeoidea. We demonstrated that the use of spermiotaxonomy supported the molecular phylogeny. Because there are many questions about the relationships among the members of the suborder Dendrobranchiata, our approach in an integrative analysis of sperm ultrastructure and molecular data and provides a new perspective that will contribute to the understanding and reclassification of the group in the near future.

\section{Acknowledgments}

The present study is part of the multidisciplinary research project BIOTA supported by the São Paulo Research Foundation FAPESP (\#2010/50188-8 and \#2016/25344-2) and the Coordenação de Aperfeiçoamento de Nível Superior - CAPES - Ciências do Mar II (\#1989/2014-23038.004309/2014-51, \#2005/2014-23038.004308/ 2014-14 and \#23038.004310/2014-85) granted to FJZ, FLM, RCC, and ALC. TR was supported by a Technical Training Fellowship from the São Paulo Research Foundation (FAPESP - PhD \# 2016/ 11182-0; TT3 \# 2012/14686-9). TR and NR also express their appreciation for the Masters and $\mathrm{PhD}$ fellowship support from CAPES, respectively. FJZ, FLM and RCC acknowledge the receipt of research grants from the Conselho Nacional de Desenvolvimento Científico e Tecnológico - CNPq (Universal \#486337/2013-8 to FJZ, PQ 304968/2014-5 to FLM, 305919/2014-8 to RCC and 308653/ 2014-9 to ALC). Additional thanks are due to Márcia F. Mataqueiro for the technical support, to the fisherman Djalma Rosa, to the Electron Microscopy Laboratory of UNESP - FCAV, and to R/V Soloncy Moura's team and CEPSUL/IBAMA for deep water sampling. We also to thank Dr. João Alberto Farinelli Pantaleão for the diagrammatic drawing of sperm cells and the anonymous reviewers for all comments and suggestions. This study was conducted in accordance with Brazilian laws (FJZ - MMA SisBio permanent license \#34587-1; permanent license to FLM for the collection of Zoological Material No. 11777-1 MMA/IBAMA/ SISBIO).

\section{References}

Alfaro, J.M., Muñoz, N., Vargas, M., Komen, J., 2003. Induction of sperm activation in open and closed thelycum penaeiod shrimps. Aquaculture 216, 371-381.

Alfaro, J.M., Ulate, K., Vargas, M., 2007. Sperm maturation and capacitation in the open thelycum shrimp Litopenaeus (Crustacea: Decapoda: Penaeoidea). Aquaculture 270, 436-442.

Alfaro-Montoya, J., 2010. The reproductive conditions of male shrimps, genus Penaeus, sub-genus Litopenaeus (open thelycum penaeoid shrimps): a review. Aquaculture 300, 1-9.

Bauer, R.T. 1991. Sperm transfer and storage structures in penaeoid shrimp: a functional and phylogenetic perspective. In: Bauer, R.T., Martin, J.W. (Eds.), Crustacean Sexual Biology. Columbia University Press, New York, pp. 183-207.

Bauer, R.T., Cash, C.E., 1991. Spermatophore structure and anatomy of the ejaculatory duct in Penaeus setiferus, $P$. duorarum and P. aztecus (Crustacea: Decapoda): homologies and functional significance. T. Am. Microsc. Soc. 110, 144-162.

Bauer, R.T., Min, L.J., 1993. Spermatophores and plug substance of the marine shrimp Trachypenaeus similis (Crustacea: Decapoda: Penaeidae): formation in the male reproductive tract and disposition in the inseminated female. Biol. Bull. 185, 174-185.

Braga, A.L., Nakayama, C.L., Poersch, L., Wasielesky, W., 2013a. Unistellate spermatozoa of decapods: comparative evaluation and evolution of the morphology. Zoomorphology 132, 261-284.

Braga, A.L., Nakayama, C.L., Castro, L.A.S., Wasielesky, W., 2013b. Spermatozoa ultrastructure of the pink shrimp Farfantepenaeus paulensis (Decapoda: Dendrobranchiata). Acta Zool. 20, 1-6.

Braga, A.L., Castro, L.A.S., Poersch, L., Wasielesky, W., 2014. Spermatozoal capacitation of pink shrimp Farfantepenaeus paulensis. Aquaculture 430, 207-210.

Bremer, J.R.A., Ditty, J.G., Turner, J.S., Saxton, B.L., 2010. Molecular species identification of commercially important penaeid shrimp from the Gulf of Mexico using a multiplex haplotype-specific PCR assay. Biochem. Sys. Ecol. 38, 715-721.

Burkenroad, M.D., 1983. Natural classification of Dendrobranchiata, with a key to recent genera. In: Schram, F.R. (Ed.), Crustacean Phylogeny. A.A. Balkema Press, Rotterdam, pp. 279-290.

Camargo, T.R., Rossi, N., Castilho, A.L., Costa, R.C., Mantelatto, F.L., Zara, F.J., 2016. Integrative analysis of sperm ultrastructure and molecular genetics supports the phylogenetic positioning of the sympatric rock shrimps Sicyonia dorsalis and Sicyonia typica (Decapoda, Sicyoniidae). Zoomorphology 135, 67-81.

Carvalho-Batista, A., Negri, M., Pileggi, L.G. Castilho, A.L. Costa, R.C., Mantelatto, F.L. 2014. Inferring population connectivity across the range of distribution of the stiletto shrimp Artemesia longinaris Spence Bate, 1888 (Decapoda, Penaeidae) from DNA barcoding: implications for fishery management. Zookeys 457, 271-288.

Castelo-Branco, T., Silva, E.F., Calazans, N., Soares, R., Peixoto, S., 2014. Scanning electron microscopic investigation of the spermatophore and spermatozoa of the shrimp Farfantepenaeus subtilis (Decapoda: Penaeidae). Invertebr. Reprod. Dev. 58, 190-192.

Chan, T.Y., Tong, J., Tam, Y.K., Chu, K.H., 2008. Phylogenetic relationships among the genera of the Penaeidae (Crustacea: Decapoda) revealed by mitochondrial $16 \mathrm{~S}$ rRNA gene sequences. Zootaxa 1694, 38-50.

Chow, S., Dougherty, M.M., Dougherty, W.J., Sandifer, P.A., 1991. Spermatophore formation in the white shrimps Penaeus setiferus and P. vannamei. J. Crustac. Biol. 11, 201-216.

Clark Jr. W.H., Talbot, P., Neal, R.A., Mock, C., Salser, B.R., 1973. In vitro fertilization with non motile spermatozoa of the brown shrimp Penaeus aztecus. Mar. Biol. 22, 353-354.

Costa, R.C., Fransozo, A., Melo, G.A.S., Freire, F.A.M., 2003. An illustrated key for Dendrobranchiata shrimps from the northern coast of São Paulo state, Brazil. Biota Neotrop 3, 1-12.

De Grave, S., Fransen, C.H.J.M., 2011. Carideorum catalogus: the recent species of the Dendrobranchiate, Stenopodidean, Procaridean and Caridean shrimps (Crustacea: Decapoda). Zool. Med. 85, 195-589.

Demestre, M., Fortuñu, J.M., 1992. Reproduction of the deep-water shrimp Aristeus antennus (Decapoda, Dendrobranchiata). Mar. Ecol. Prog. Ser. 84, 41-51.

Dougherty, W.J., Dougherty, M.M., 1989. Electron microscopical and histochemical observations on melanized sperm and spermatophores of pond-cultured shrimp, Penaeus vannamei. J. Invert. Pathol. 54, 331-343.

Fransozo, V., Lopes-Greco, LS., Bambozzi, A Santos, D.C.D., Gregati, R.A., Zara, FJ.Z. 2016. Functional morphology of the male reproductive system of the white shrimp Litopenaeus schmitti (Burkenroad, 1936) (Crustacea, Penaeidea) compared to other Litopenaeus. Invertebr. Reprod. Dev. 1-14.

Huelsenbeck, J.P., Ronquist, F., 2001. MRBAYES: Bayesian inference of phylogeny. Bioinformatics 17, 754-755.

Huelsenbeck, J.P., Ronquist, F., Nielsen, R., Bollback, J.P., 2001. Bayesian inference of phylogeny and its impact on evolutionary Biology. Science 294, 2310-2314.

Jamieson, B.G.M., 1991. Ultrastructure and phylogeny of crustacean spermatozoa. Mem. Queensl. Mus. 31, 109-142.

Jamieson, B.G.M., Tudge, C.C., 2000. Crustacea-Decapoda. In: Adiyodi, K.G. Adiyodi, R.G., Jamieson, B.G.M. (Eds.), Reproductive Biology of Invertebrates, Progress in Male Gamete Ultrastructure and Phylogeny, vol. 9C. Wiley, Chichester, pp. 1-95.

Kleve, M.G., Yudin, A.I., Clark Jr., W.H., 1980. Fine structure of the unistellate sperm of the shrimp, Sicyonia ingentis (Natantia). Tissue Cell 12, 29-45.

Kruevaisayawan, H., Vanichviriyakit, R., Weerachatyanukul, W., Iamsaard, S., Withyachumnarnkul, B., Basak, A., Tanphaichitr, N., Sobhon, P., 2008. Induction 
of the acrosome reaction in black tiger shrimp (Penaeus monodon) requires sperm trypsin like enzyme activity. Biol. Reprod. 79, 134-141.

Krol, R.M., Hawkins, W.E., Overstreet, R.M., 1992. Reproductive components. In: Harrison, F.W., Humes, A.G. (Eds.), Microscopic Anatomy of Invertebrates. Wiley-Liss Inc., New York, pp. 295-343.

Ma, K.Y., Chan, T.Y., Chu, K.H., 2009. Phylogeny of penaeoid shrimps (Decapoda: Penaeoidea) inferred from nuclear protein-coding genes. Mol. Phylog. Evol. 53, 45-55.

Mantelatto, F.L., Robles, R., Felder, D.L., 2007. Molecular phylogeny of the Western Atlantic species of the genus Portunus (Crustacea, Brachyura, Portunidae). Zool. J. Linn. Soc. 150, 211-220.

Maggioni, R., Rogers, A.D., Maclean, N., D'Incao, F., 2001. Molecular phylogeny of western Atlantic Farfantepenaeus and Litopenaeus shrimp based on mitochondrial 16S partial sequences. Mol. Phylog. Evol. 18, 66-73.

Malek, S.R.A., Bawab, F.M., 1974. The formation of the spermatophore in Penaeus kerathurus (Forskal, 1775) (Decapoda, Penaeidae): the initial formation of a sperm mass. Crustaceana 26, 273-285.

Matzen-da-Silva, J., Creer, S., Santos, A., Costa, A.C., Cunha, M.R., Costa, F.O., Carvalho, G.R., 2011. Systematic and evolutionary insights derived from mtDNA COI barcode diversity in the Decapoda (Crustacea: Malacostraca). PlosOne 6, e19449.

Medina, A., 1994. Spermiogenesis and sperm structure in the shrimp Parapenaeus longirostris (Crustacea: Dendrobranchiata): comparative aspects among decapods. Mar. Biol. 119, 449-460.

Medina, A., Mourente, G., Lopez de la Rosa, I., Santos, A., Rodriguez, A., 1994a. Spermatozoal ultrastructure of Penaeus kerathurus and Penaeus japonicus (Crustacea, Dendrobranchiata). Zoomorphology 114, 161-167.

Medina, A., López de La Rosa, I., Santos, A., 1994b. Ultrastructural comparison of the spermatozoa of Sicyonia carinata (Sicyoniidae) and Penaeopsis serrata (Penaeidae) shrimps (Crustacea, Dendrobranchiata), with particular emphasis on the acrosomal structure. J. Submicrosc. Cytol. Pathol. 26, 395-403.

Medina, A., 1995. Spermatozoal ultrastructure in Dendrobranchiata (Crustacea, Decapoda): taxonomic and phylogenetic considerations. In: Jamieson, B.G.M. Ausio, J., Justine, J.L. (Eds.), Advances in Spermatozoal Phylogeny and Taxonomy, Memoires Du Museum National D'Histoire Naturelle, vol.166, pp. 231-242. Paris.

Medina, A., García-Isarch, E., Sobrino, I., Abascal, F.J., 2006a. Ultrastructure of the spermatozoa of Aristaeopsis edwardsiana and Aristeus varidens (Crustacea, Dendrobranchiata, Aristeidae). Zoomorphology 125, 39-46.

Medina, A., Scelzo, M.A., Tudge, C.C., 2006b. Spermatozoal ultrastructure in three Atlantic Solenocerid shrimps (Decapoda, Dendrobranchiata). J. Morphol. 267, 300-307.

Pérez Farfante, I., 1988. Illustrated Key to Penaeoid Shrimps of Commerce in the Americas. US Department of Commerce, National Oceanic and Atmospheric Administration, National Marine Fisheries Service.

Pérez Farfante, I., Kensley, B., 1997. Penaeiod and Sergestoid Shrimp and Prawns of the World: Keys and Diagnostis for the Families and Genera. Mémoires du Muséum National d' Histoire Naturalle, Paris, pp. 175-233.
Posada, D., 2008. jModelTest: phylogenetic model Averaging. Mol. Biol. Evol. 25 $1253-1256$.

Quan, J., Zhuang, Z., Deng, J., Dai, J., Zhang, Y.P., 2004. Phylogenetic relationships of 12 Penaeoidea shrimp species deduced from mitochondrial DNA sequences. Biochem. Genet. 42, 331-345.

Rambaut, A., 2009. FigTree Version 1.3.1 [computer program]. Available in. http:// tree.bio.ed.ac.uk.

Reynolds, E.S., 1963. The use of lead citrate at high ph as an electron-opaque stain in electron microscopy. J. Cell Biol. 17, 208-212.

Ro, S., Talbot, P., Leung-Trujillo, J., Lawrence, A.L., 1990. Structure and function of the vas deferens in the shrimp Penaeus setiferus: Segments 1-3. J. Crust Biol. 10, 455-468.

Rossi, N., 2016. Estudo taxonômico e filogenético das espécies de camarão do gênero Sicyonia (Dendrobranchiata: Sicyoniidae), ocorrentes no continente Americano: dados morfológicos e moleculares (Ph.D. thesis). Faculdade de Filosofia, Ciências e Letras de Ribeirão Preto, Universidade de São Paulo, Ribeirão Preto.

Scelzo, M., Medina, A., 2003. Spermatozoal ultrastructure in Artemesia longinaris (Decapoda, Penaeidae). J. Crust. Biol. 23, 814-818.

Scelzo, M., Medina, A., 2004. A Dendrobranchiate, Peisos petrunkevitchi (Decapoda Sergestidae) with reptant like sperm: a spermiocladistic assessement. Acta Zool. 85, 81-89.

Teodoro, S.S.A., Terossi, M., Mantelatto, F.L. Costa, R.C., 2016. Discordance in the identification of juvenile pink shrimp (Farfantepenaeus brasiliensis and F. paulensis: family Penaeidae): an integrative approach using morphology morphometry and barcoding. Fish. Res. 183, 244-253.

Thompson, J.D., Higgins, D.G., Gibson, T.J., 1994. Clustal W, improving, the position the sensitivity of progressive multiple sequence alignment through sequence weighting, position specific, gap penalties and weight matrix choice. Nucleic Acid. Res. 22, 4673-4680.

Tudge, C.C., 2009. Spermatozoal morphology and its bearing on decapod phylogeny. In: Martin, J.W., Crandall, K.A., Felder, D.L. (Eds.), Decapod Crustacean Phylogenetics, Crustacean, vol. 18. Taylor and Francis/CRC Press, Boca Raton, pp. 101-119.

Vazquez-Bader, A.R. Carrero, J.C. Garcia-Varela, M., Gracia, A., Laclette, J.P. 2004 Molecular phylogeny of Superfamily Penaeoidea Rafinesque-Schmaltz, 1815 based on mitochondrial $16 \mathrm{~S}$ partial sequence analysis. J. Shellfish Res. 23 911-918.

Venable, J.H., Coggeshall, R., 1965. A simplified lead citrate stain for use in electron microscopy. J. Cell Biol. 25, 407-408.

Yang, C.H., Sha, Z., Chan, T.Y., Liu, R., 2015. Molecular phylogeny of the deep-sea penaeid shrimp genus Parapenaeus (Crustacea: Decapoda: Dendrobranchiata). Zool. Scr. 44, 312-323.

Zheng, L.M., Cao, W.Q., Fang, L.P., Zhou, M.Y., Lin, Y.S., 2005. Mitochondrial DNA COI sequence analysis of Litopenaeus vannamei. J. Xiamen Univ. 44, 815-820. 